\title{
Understanding wetland sub-surface hydrology using geologic and isotopic signatures
}

\author{
P. K. Sikdar and P. Sahu \\ Department of Environment Management, Indian Institute of Social Welfare and Business Management, \\ Kolkata 700073, India
}

Received: 5 February 2009 - Published in Hydrol. Earth Syst. Sci. Discuss.: 8 April 2009

Revised: 24 June 2009 - Accepted: 19 July 2009 - Published: 28 July 2009

\begin{abstract}
This paper attempts to utilize hydrogeology and isotope composition of groundwater to understand the present hydrological processes prevalent in a freshwater wetland, source of wetland groundwater, surface water/groundwater interaction and mixing of groundwater of various depth zones in the aquifer. This study considers East Calcutta Wetlands (ECW) - a freshwater peri-urban inland wetland ecosystem located at the lower part of the deltaic alluvial plain of South Bengal Basin and east of Kolkata city. This wetland is well known over the world for its resource recovery systems, developed by local people through ages, using wastewater of the city. Geological investigations reveal that the sub-surface geology is completely blanketed by the Quaternary sediments comprising a succession of silty clay, sand of various grades and sand mixed with occasional gravels and thin intercalations of silty clay. At few places the top silty clay layer is absent due to scouring action of past channels. In these areas sand is present throughout the geological column and the areas are vulnerable to groundwater pollution. Groundwater mainly flows from east to west and is being over-extracted to the tune of $65 \times 10^{3} \mathrm{~m}^{3} /$ day. $\delta^{18} \mathrm{O}$ and $\delta \mathrm{D}$ values of shallow and deep groundwater are similar indicating resemblance in hydrostratigraphy and climate of the recharge areas. Groundwater originates mainly from monsoonal rain with some evaporation prior to or during infiltration and partly from bottom of ponds, canals and infiltration of groundwater withdrawn for irrigation. Relatively high tritium content of the shallow groundwater indicates local recharge, while the deep groundwater with very low tritium is recharged mainly from distant areas. At places the deep aquifer has relatively high tritium, indicating mix-
\end{abstract}

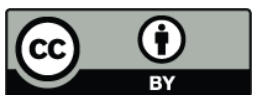

Correspondence to: P. K. Sikdar (p_sikdar@hotmail.com) ing of groundwater of shallow and deep aquifers. Metals such as copper, lead, arsenic, cadmium, aluminium, nickel and chromium are also present in groundwater of various depths. Therefore, aquifers of wetland and surrounding urban areas which are heavily dependent on groundwater are vulnerable to pollution. In the area south of ECW isotope data indicates no interaction between shallow and deep aquifer and hence this area may be a better location to treat sewage water than within ECW. To reduce the threat of pollution in ECW's aquifer, surface water-groundwater interaction should be minimized by regulating tubewell operation time, introducing treated surface water supply system and artificial recharging of the aquifer.

\section{Introduction}

Freshwater wetlands are characterized by significant temporal and spatial variations in sediment types. These will reflect the wetland hydrostratigraphy and will produce distinctive aquifer system that reflects depositional history and changes in groundwater source. Such wetlands are characterized by a hydrological cycle in which the groundwater within the wetland may be recycled from local and/or distant areas and will comprise varying quantities of water derived from precipitation, surface water bodies and return flow of groundwater used for irrigation in nearby irrigated land.

Many wetland hydrology studies have described the wetland water table or developed an annual water budget (Owen, 1995; Cooper et al., 1998) to illustrate the link between wetland hydrology and ecology (Drexler et al., 1999). These studies often fail to represent the variability in wetland hydrological process adequately, especially the ever increasing human-induced pressures on groundwater. It is therefore, imperative to identify the depositional condition of wetlands

Published by Copernicus Publications on behalf of the European Geosciences Union. 
through surface and sub-surface sediment disposition, water level trend and heavy metal concentration in groundwater.

Determining the stable isotope ratios of groundwater $\left(\delta^{18} \mathrm{O}\right.$ and $\left.\delta \mathrm{D}\right)$ and radioactive isotope (Tritium) content may explain wetland hydrological dynamics in a better way. Variation in stable isotope composition can classify patterns of groundwater recharge and flow and have been used to estimate groundwater residence time (Soulsby et al., 2000). Isotopes have also been used to investigate the seasonal dynamics in wetland water storage (Clay et al., 2004). However, comparatively few studies have used isotope to determine groundwater sources of inland wetland, to discriminate sources of groundwater recharge and to understand mixing and contamination processes of groundwater. This paper attempts to utilize hydrogeologic and isotopic signatures to understand the present hydrological processes, sources of inland wetland groundwater, surface water/groundwater interaction and mixing and/or contamination of groundwater of various depth zones.

\section{Methodology}

This study was undertaken in and around an inland freshwater wetland of India, known as East Calcutta Wetlands $(\mathrm{ECW})$. The ECW is a complex of natural and human-made wetlands lying east of the city of Kolkata (previously known as Calcutta) in Eastern India. This wetland covers an area of $125 \mathrm{sq} \mathrm{km}$ and comprises intertidal marshes such as salt marshes and salt meadows with significant wastewater treatment areas including sewage farms, settling ponds and oxidation basins. This wetland is well known over the world for its multiple uses. It treats about $800 \times 10^{3} \mathrm{~m}^{3}$ of wastewater flowing out daily from Kolkata and has saved the city from constructing and maintaining a wastewater treatment plant. ECW is a perfect example of wise-use of wetland ecosystem where city sewage is used for traditional practices of fisheries and agriculture. This wetland ecosystem is one of the rare examples of combination of environmental protection and development management where a complex ecological process has been adopted by the local farmers by mastering the resource recovery activities. Therefore, ECW has been declared as a Ramsar site on 19 August 2002 (Ramsar site no. 1208) (Source: www.ramsar.org/sitelist.htm) and has acquired an international status.

The study area covers about $334 \mathrm{sq} \mathrm{km}$. It is bounded by latitude $22^{\circ} 25^{\prime} \mathrm{N}$ to $22^{\circ} 40^{\prime} \mathrm{N}$ and longitudes $88^{\circ} 20^{\prime} \mathrm{E}$ to $88^{\circ} 35^{\prime} \mathrm{E}$ (Fig. 1) and lies between River Hugli in the northwest and River Bidyadhari in the east. The area is a part of the lower deltaic plain of the Bhagirathi-Ganga river system and is entirely covered by fluviatile sediments of Quaternary age. The elevation of the land varies between $3 \mathrm{~m}$ and $6.5 \mathrm{~m}$ above the mean sea level and slopes gradually towards south and southeast. The solid waste dumping ground of Kolkata city is on the western fringe of ECW at Dhapa (Fig. 1). Solid

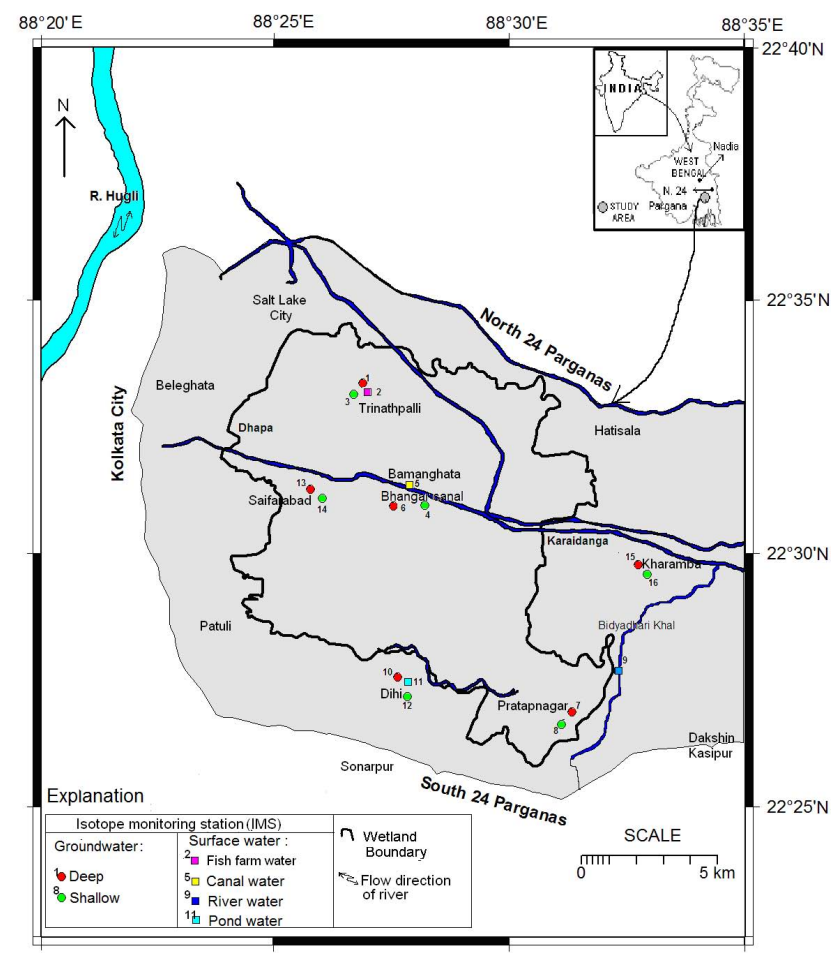

Fig. 1. Location map of the area along with isotope monitoring stations.

waste dumping started in 1870 and at present more than $95 \%$ of the total waste generated in Kolkata city is disposed here. This area may also act as an important source of contamination of groundwater of the area. Pumping of groundwater beneath Kolkata city is causing flow of groundwater from the wetland to the city well fields (Fig. 2). Therefore, if any local recharge from the wetland or solid waste dumping ground to the aquifer beneath ECW takes place, it may be detrimental to the city water quality. Moreover, in the near future, industrial activities in the Calcutta Leather Complex (CLC) project area located just outside the eastern boundary of ECW at Karaidanga (Fig. 1) are likely to increase. This would require an additional $30 \times 10^{3} \mathrm{~m}^{3} /$ day of water from the already stressed aquifer.

Sub-surface distribution of the lithounits has been ascertained from 109 lithological logs and 57 Vertical Electrical Sounding (VES) data, collected from different government and private agencies. Depths of the boreholes range from $24 \mathrm{~m}$ to $304 \mathrm{~m}$ and that of VES data ranges from $25 \mathrm{~m}$ to 434 m. Using lithologs and VES data, an isopach map of top silty clay bed (Fig. 3 ) and a three-dimensional fence diagram (Fig. 4) of the area have been constructed.

To understand the regional groundwater flow pattern of the study area, trend surface analysis of the piezometric surface elevation data was carried out. Fitting of trend surface is essentially a statistical technique involving non-orthogonal polynomials. Trend surface analysis has been carried out to 


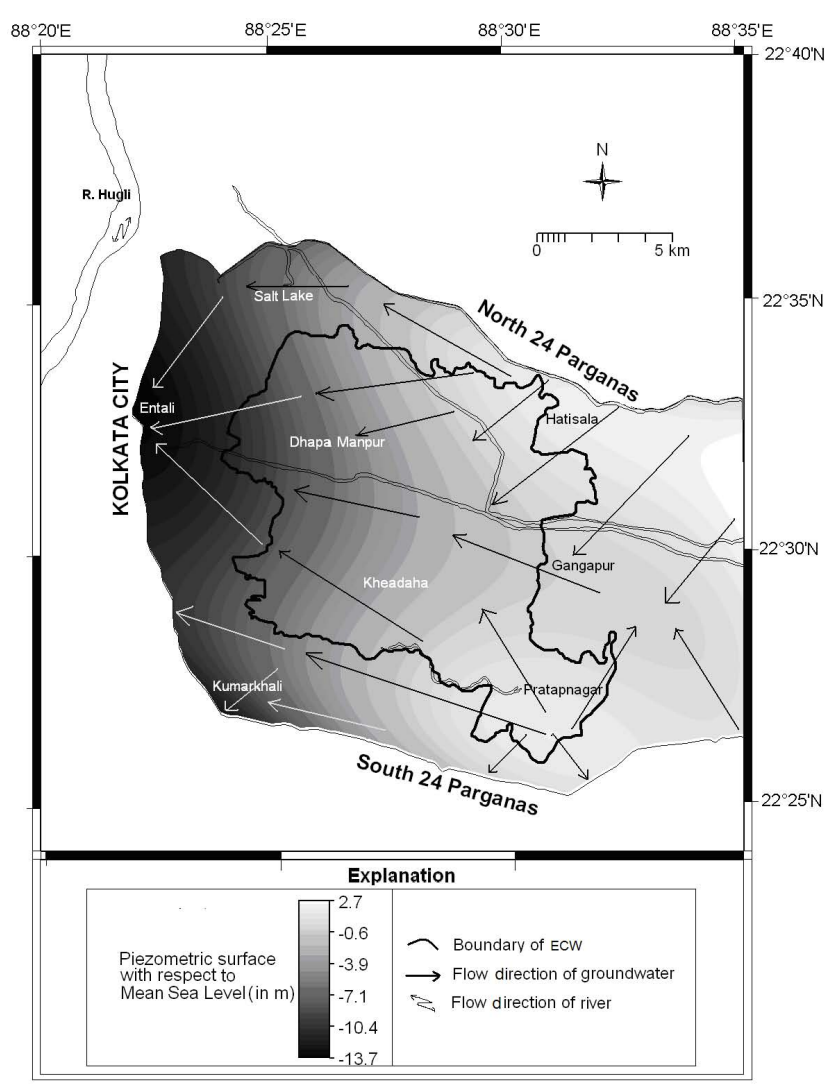

Fig. 2. Fourth degree trend surface map of pre-monsoon, 2005.

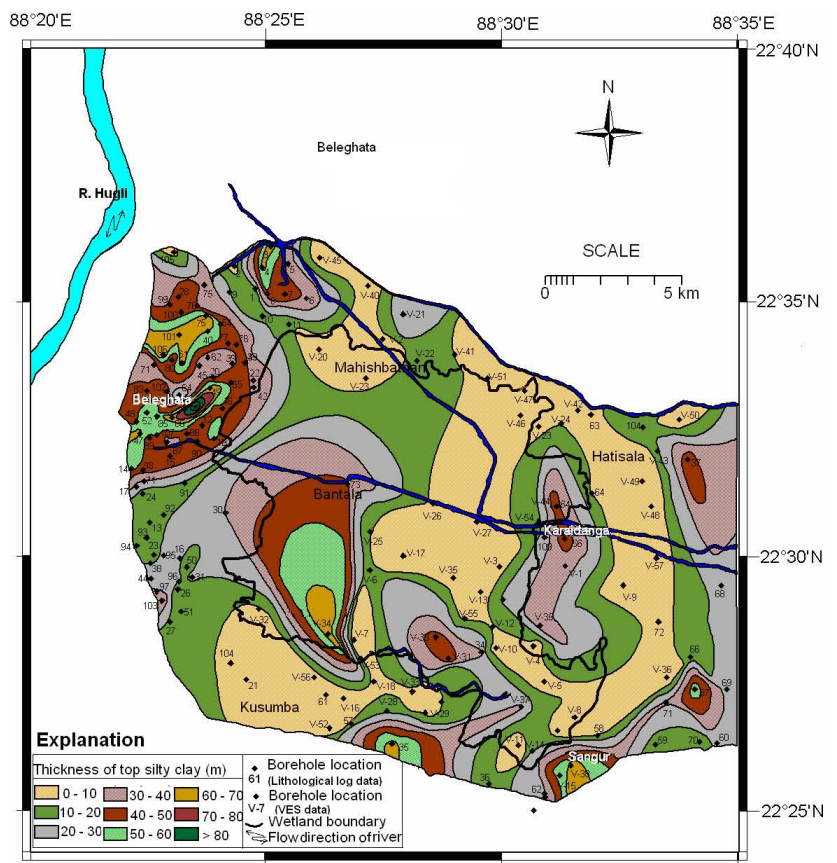

Fig. 3. Isopach map of top silty clay bed of the area.

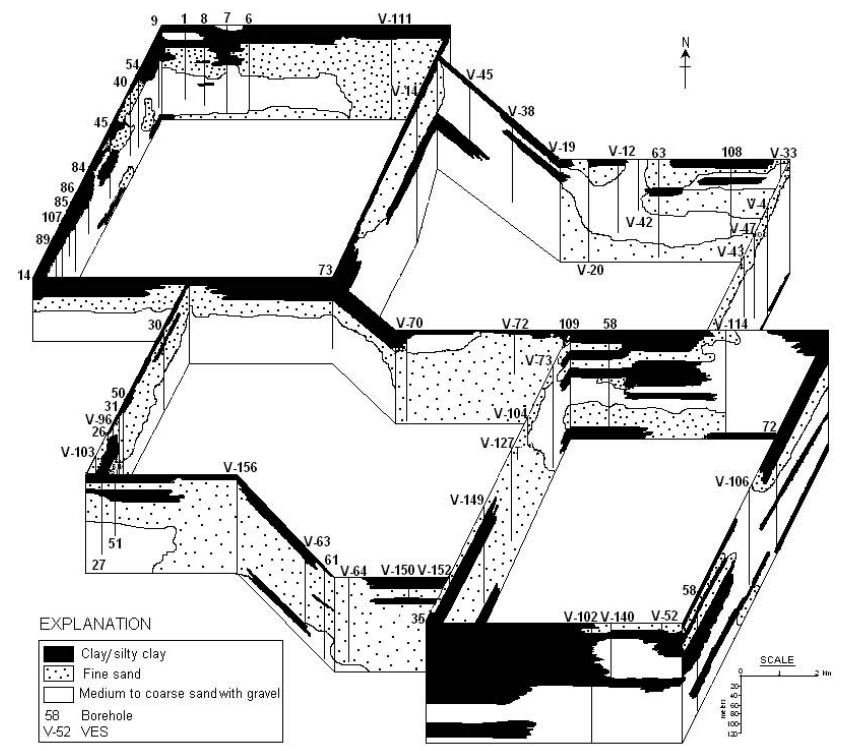

Fig. 4. Fence diagram depicting the subsurface geology of the area.

separate the local fluctuations in water levels from the major flow system by fitting a mathematical surface to the piezometric surface elevation data represented on a map. The principle of least squares has been used to compute the surface of best possible fit. The computed surface is such that the sum of squares of the distances between the observed elevations of the water level and the corresponding point on the mathematically fitted surface is the least. ILWIS 3.3 Academic version was used to compute polynomial trend surfaces up to sixth degree. The goodness of fit increases with increase in the degree of trend surface. A sharp change in goodness of fit is recorded between third order and fourth order. Therefore, fourth order trend surface having a goodness of fit of $91 \%$ has been utilized to understand the regional groundwater flow pattern.

For stable isotope (oxygen- $\delta^{18} \mathrm{O}$ and hydrogen- $\delta \mathrm{D}$ ) analysis, eight groundwater and four surface water samples were collected from the area during the month of June 2006 from twelve isotope monitoring stations (IMS) (Fig. 1). Among the eight groundwater samples, four were collected from the shallow aquifer (depth $<50 \mathrm{~m}$ ) and rest were collected from the deep aquifer (depth $>50 \mathrm{~m}$ ). Surface water was collected from a fish farm, Bhangar canal, River Bidyadhari and a pond. At each location, along with two groundwater samples of different depths, any one of the four types of surface water, present in around the same location were collected. Before collecting groundwater samples, the selected wells were purged for 30 to $35 \mathrm{~min}$. Each bottle $(100 \mathrm{ml}$ Teflon bottle) was rinsed for several times using the well water to remove any kind of impurities present in those bottles. The bottle was then completely filled with water taking care that no air bubble was trapped within the water sample. Then to prevent evaporation, the double plastic caps of the bottles 
Table 1. Stratigraphy of the area in and around ECW.

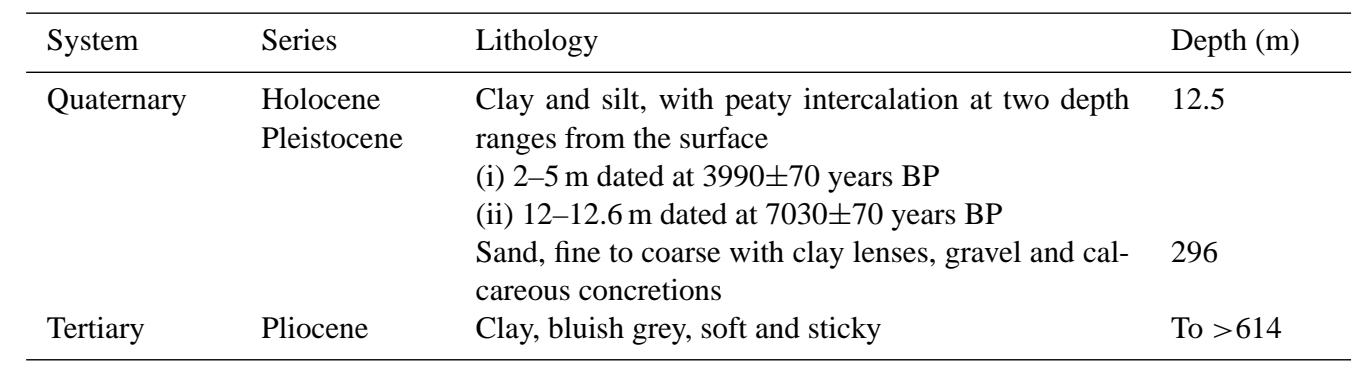

Source: Sikdar, 2000.

were sealed. During sampling of surface water proper care was taken to avoid air bubbles and sealing the mouth of the bottle. Stable isotope analyses for the water samples were carried out at the Indian Institute of Technology, Kharagpur using a Finnigan Mat Delta Plus XP continuous flow isotope ratio mass spectrometer and the samples were measured in gas bench. The analyses were standardized against the international references Vienna-Standard Mean Ocean Water (VSMOW), Greenland Ice Sheet Project (GISP), and Standard Light Antarctic Precipitation (SLAP), as well as internal standards STAILIT (IIT Standard).

For radioactive isotope (tritium) analysis, twelve groundwater samples were collected from the isotope monitoring stations during the month of June 2006 (Fig. 1). Six groundwater samples were collected from the shallow aquifer and rest from the deep aquifer. Tritium analysis of groundwater samples was carried out at the isotope laboratory of the United States Geological Survey (USGS). The samples were analyzed by electrolytic enrichment and liquid scintillation counting.

\section{Results}

\subsection{Sub-surface geology}

The sub-surface geology of the area is completely blanketed by the Quaternary fluviatile sediments comprising a succession of silty clay, sand and sand mixed with occasional gravel. In some places along with silty clay, sticky clay is also present at the top of the lithological column. Lithologs of deep exploratory boreholes, drilled by various agencies suggests the existence of underlying Tertiary clay/silty clay at an average depth of $296 \mathrm{~m}$ (Sikdar, 2000; Mukherjee et al., 2007). This formation continues up to a depth of at least $614 \mathrm{~m}$ below the ground surface. Therefore, the Quaternary aquifer of the area is sandwiched between two aquitards made of silty clay/clay and is more or less continuous in nature. These two fine grained beds are dark gray in colour, sticky and plastic to semi plastic in character and also contain stringers of silt or fine sand. The top aquitard is underlain by a sequence of fine to coarse sand horizon mixed occasionally with gravel. The continuity of the sand layer that forms the aquifer is broken by occasional clay lenses of limited lateral extent. The Quaternary stratigraphy of the area (Table 1) has been compiled on the basis of lithological, floral, faunal and radiocarbon dating (Sen and Banerjee, 1990; Barui and Chanda, 1992; Hait et al., 1996; Sikdar, 2000).

The sands contain high amount of mica. The average median diameter (Folk, 1968) of the sands of the upper horizon $(<84 \mathrm{~m})$ is $1.29 \varnothing$ while those of the lower horizon $(>84 \mathrm{~m})$ is $0.93 \varnothing$ and the sediments are poor to moderately sorted. This grain size distribution and the fining upward sequence of the Quaternary sediments reflect a fluvio-deltaic depositional environment (Allen, 1965). Occurrence of two peat layers in the upper horizons of the sediments and occurrence of marsh or salt lakes in the central part of the area indicate prevalence of bog and marshy conditions towards the close of sedimentation.

The yellow colour of the sand (at a depth range of $24 \mathrm{~m}$ to $76 \mathrm{~m}$ ) is thought to be due to oxidation of the sediments generated from the Archean terrain of the Chotonagpur Plateau and brought down by the easterly flowing rivers. The grey to light grey colour of overlying sediments might indicate Himalayan provenance, deposited under reducing condition during the late Quaternary period (Sikdar, 2000).

The lithologs of the deep and shallow boreholes also show the occurrence of a thick silty clay bed at the top of the geological succession. The spatial variation in thickness of this top aquitard in different parts of the area is shown in Fig. 3. The thickness of this bed shows an overall increase from north to south. At places the top silty clay bed is conspicuously absent and in these areas sand occurs from the top of the geological sequence.

A fence diagram, (Fig. 4) correlating the lithologs of favourably located boreholes and VES data, have been constructed to obtain a three-dimensional view of the subsurface disposition of the sediments underlying the area. This fence diagram presents an overall picture of the disposition of sediments down to a depth of $200 \mathrm{~m}$ below the land surface. However, this diagram do not reveal the bottom silty clay bed as 
their depth is restricted to $200 \mathrm{~m}$. In deep boreholes a fining upward sequence has been noticed from the bottom silty clay bed. At the lower horizon of the sedimentary column, coarse sediments represented by gravel and coarse sand grade into medium to fine sand and then to silty clay in the upper horizon (Sikdar, 2000). The top silty clay bed is underlain by a sandy sequence grading from fine to coarse. Thin intercalations of silty clay are also present within the sandy sequence. In the western part of the area, top silty clay bed is very thick, generally $40 \mathrm{~m}$ and above. But the silty clay layer is conspicuously absent at few places in east, north, south and central parts of the area due to the scouring action of past channels of River Bidyadhari. In these areas sands of various grades are observed throughout the geological column. Therefore, these zones are highly vulnerable to groundwater pollution and groundwater quality deterioration.

\subsection{Groundwater condition}

The sub-surface geological set up as discussed above indicates that the groundwater occurs under confined to semiconfined condition. However, at some places in the area the top confining bed is either less than $10 \mathrm{~m}$ thick or is absent. Places where the top confining bed is absent, a thick column of sand occurs from the top of the geological succession indicating channel deposition. These pockets, where groundwater occurs under unconfined condition, act as recharge area.

Though the topography of the area in and around ECW is more or less flat, local groundwater mounds and troughs have developed due to various rates of groundwater withdrawal at different places. Fourth degree trend surface map of premonsoon, 2005 (Fig. 2) indicates that the regional flow of groundwater within the area is from east to west and is controlled by a groundwater trough defined by the $13.7 \mathrm{~m}$ below mean sea level contour near south-central Kolkata (Sahu and Sikdar, 2007). Therefore, any leakage of contaminated water from ECW and Dhapa solid waste dumping ground may pollute Kolkata's aquifer.

Pumping test carried out at 12 locations by Geological Survey of India (GSI), Central Ground Water Board (CGWB) and Calcutta Leather Complex Project Authority indicates that the aquifer occurring in and around the northern part of the area has greater potentiality with transmissivity ranging from $3447 \mathrm{~m}^{2} /$ day to $6514 \mathrm{~m}^{2 /}$ day (average: $5063 \mathrm{~m}^{2} /$ day). The potentiality of the aquifer in the southern part is much lower compared to that of the northern part and the transmissivity ranges between $640 \mathrm{~m}^{2} /$ day and $2318 \mathrm{~m}^{2} /$ day (average: $1567 \mathrm{~m}^{2} /$ day). In the western part the transmissivity value is about $2065 \mathrm{~m}^{2} /$ day. In the eastern part, the aquifer has the highest potential with transmissivity of $9935 \mathrm{~m}^{2} /$ day (Chaterji et al., 1964; Niyogi et al., 1966; Ghosh and Roy, 1996; Banerjee and Khan, 1982; Misra, 2001). Storage coefficient of the aquifer ranges from $3.78 \times 10^{-5}$ to $3.3 \times 10^{-3}$ and indicates confined to semiconfined nature of the aquifer.
By applying the predictive method of Masch and Denny (1966), hydraulic conductivity has been determined for 223 samples, systematically collected during drilling operations at regular intervals from 8 boreholes drilled in and around ECW. The hydraulic conductivity of the aquifer material of different depths varies from $6 \mathrm{~m} /$ day to about $55 \mathrm{~m} /$ day.

Long term piezometric surface data collected by different workers during the premonsoon period of 1956-1958 (Chaterji et al., 1964), 1980-1981, 1985 (Biswas and Saha, 1986), 1993-1994 (Sikdar, 1996), 1976-1998 (Misra, 2001) and 2004-2005 (present study) indicates that the average recession rate of depth to piezometric surface ranges from $0.10 \mathrm{~m} /$ year to $0.21 \mathrm{~m} /$ year.

The total quantity of groundwater flowing into the area has been estimated by applying Darcy's equation of flow of fluids through porous media. The total quantity of groundwater that naturally flows into the area is $228 \times 10^{3} \mathrm{~m}^{3} /$ day. The total groundwater discharge, (natural outflow $=65 \times 10^{3} \mathrm{~m}^{3} /$ day and withdrawal for irrigation purpose $=124 \times 10^{3} \mathrm{~m}^{3} /$ day, for drinking purpose $=98 \times 10^{3} \mathrm{~m}^{3} /$ day and for industrial purpose $=6 \times 10^{3} \mathrm{~m}^{3} /$ day) is $293 \times 10^{3} \mathrm{~m}^{3} /$ day. Therefore, groundwater in the area is being over-extracted to the tune of $65 \times 10^{3} \mathrm{~m}^{3} /$ day. An additional abstraction of $30 \times 10^{3} \mathrm{~m}^{3} /$ day of groundwater in CLC project area will increase the stress on the aquifer which may lead to contamination of groundwater and land subsidence due to leakage of water from the overlying aquitard.

The geochemical study of the groundwater suggests that (i) the groundwater can be categorized into four hydrochemical facies which may be assigned to 3 broad types "fresh", "blended" and "brackish" and (ii) mixing of "fresh" and "brackish" water is possibly responsible for evolution of "blended" water. Absence of sodium dominated hydrochemical facies indicates medium flushing of the aquifer by freshwater. Hence, ion exchange of sodium in clay for calcium and magnesium in water by circulating water in the area is limited (Sahu and Sikdar, 2007). Sikdar and Dasgupta (1997), Mitra and Gupta (2000), Ghosh et al. (2001) and Sikdar and Bhattacharya (2003) reported the presence of arsenic, lead, cadmium, chromium, nickel and copper in groundwater of Kolkata city and ECW. Sikdar et al. (2002) also reported high concentration of aluminium (1.2-2.6 mg/l) in groundwater of ECW. This groundwater quality deterioration may be due to leaching of heavy metals from bottom of the sewage-fed fisheries to the aquifer.

\subsection{Isotope signature on hydrology}

Published studies on distribution of stable environmental isotopes $\delta^{18} \mathrm{O}$ and $\delta \mathrm{D}$ in the Bengal Basin are very limited. The earliest work on distribution of stable environmental isotopes $\delta^{18} \mathrm{O}$ and $\delta \mathrm{D}$ in the Bengal Basin was done by Dray (1983), who demonstrated that significant isotopic differences exist between groundwater and the water of the River Ganges (Padma) in Bangladesh. Several other workers such 
as Aggarwal et al. (2000); Basu et al. (2002); Stüben et al. (2003); Harvey et al. (2005); Klump et al. (2006) etc. have also used stable isotope techniques to understand hydrogeochemistry and groundwater dynamics of the Bengal Basin.

The most recent work relevant to the present area was carried out by Mukherjee (2006) and Sengupta and Sarkar (2006). Mukherjee (2006) collected sixty-four groundwater, seven river-water and fourteen rain-water samples from Gangetic West Bengal during the months of May to $\mathrm{Au}-$ gust of 2003-2005 and analysed them for $\delta^{18} \mathrm{O}$ and $\delta \mathrm{D}$. Using the rainwater data from various parts of Gangetic West Bengal (Murshidabad, Nadia, North 24-Parganas, South 24Parganas districts and Kolkata) collected during 2004 and 2005, Mukherjee (2006) generated a Local Meteoric Water Line (LMWL). The equation for the LMWL is as follows:

$\delta \mathrm{D}=7.24 \delta^{18} \mathrm{O}+7.73\left(r^{2}=0.93\right)$

Sengupta and Sarkar (2006) have also carried out analysis of $\delta \mathrm{D}$ and $\delta^{18} \mathrm{O}$ of thirty-six numbers of weekly composite precipitation samples at Barasat, nearly $20 \mathrm{~km}$ northeast of Kolkata and generated a LMWL. The equation for the LMWL is as follows:

$\delta \mathrm{D}=7.88 \delta^{18} \mathrm{O}+8.93\left(r^{2}=0.99\right)$

These LMWLs compare well to the Global MeteoricWater Line (GMWL) of Craig (1961) $\left(\delta \mathrm{D}=8 \delta^{18} \mathrm{O}+10\right)$. Craig's GMWL defines the relationship between $\delta^{18} \mathrm{O}$ and $\delta \mathrm{D}$ in worldwide fresh surface waters. In the present work, for analyzing the isotope data generated for the area in and around ECW, LMWL of Mukherjee (2006) has been used.

\subsubsection{Groundwater}

In the present area, groundwater of shallow depths has $\delta \mathrm{D}$ (\%o VSMOW) values ranging between $-32 \%$ and $-25 \%$ o and $\delta^{18} \mathrm{O}(\% \circ \mathrm{VSMOW})$ values ranging between $-4.5 \%$ and $-3.0 \%$. In deep groundwater the values of $\delta \mathrm{D}$ and $\delta^{18} \mathrm{O}$ are in the range of $-32 \%$ to $-27 \%$ and $-4.9 \%$ to $-3.3 \%$, respectively (Table 2).

To understand the influence of depth on the concentration of stable isotopes $\left(\delta^{18} \mathrm{O}\right.$ and $\left.\delta \mathrm{D}\right)$ depth-wise variation of $\delta^{18} \mathrm{O}$ has been plotted (Fig. 5a). Perusal of this plot and Table 2 reveals that there is apparently no difference between the $\delta^{18} \mathrm{O}$ and $\delta \mathrm{D}$ concentrations for both shallow and deep groundwater. This is possibly due to similarity in hydrostratigraphy and climate of the recharge areas of shallow and deep aquifers of ECW.

To understand the influence of depth on the concentration of tritium, a plot of tritium concentration versus depth has been drawn (Fig. 5b). Tritium content of groundwater from shallow and deep aquifer varies from $<0.76 \mathrm{TU}$ to $6.6 \mathrm{TU}$ and $<0.53 \mathrm{TU}$ to $4.5 \mathrm{TU}$, respectively (Table 2 ). Very low tritium content of the groundwater of deep aquifer $(<0.56$

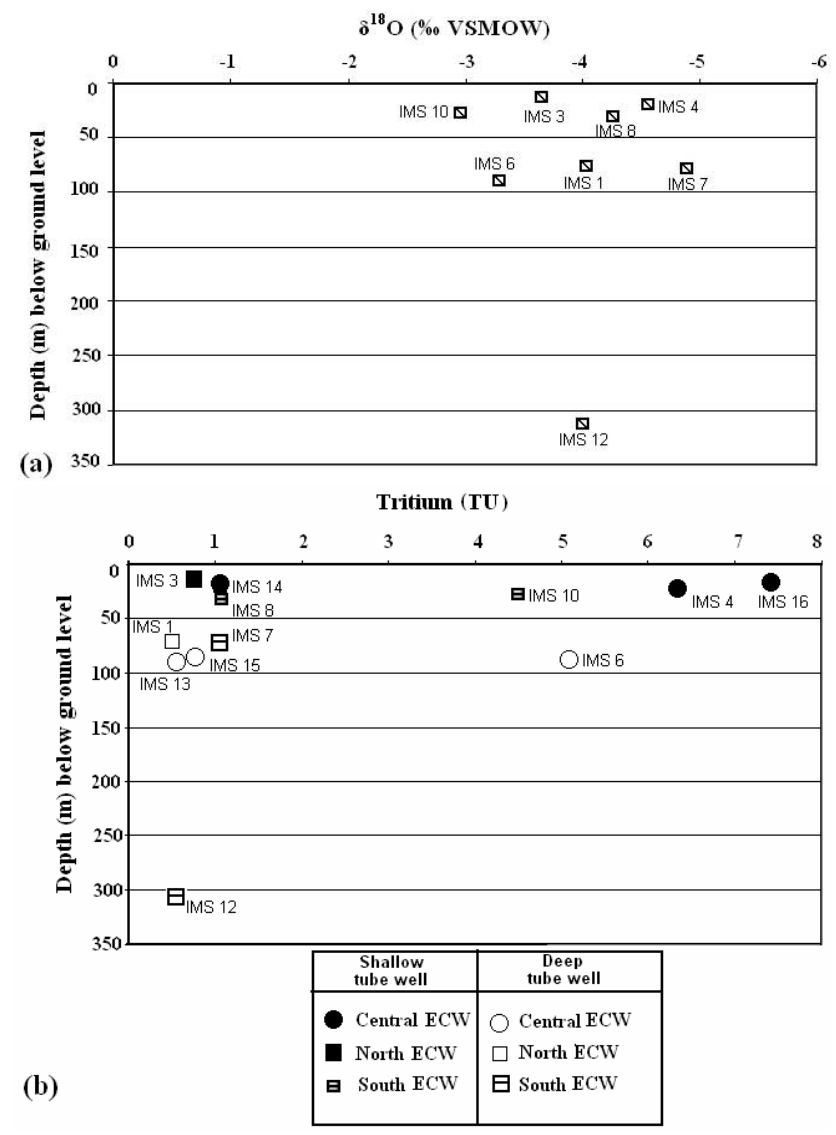

Fig. 5. Depth wise distribution of isotope in groundwater: (a) $\delta^{18} \mathrm{O}$ and (b) tritium.

TU to <1.1 TU; Table 2), except at Bamanghata (4.5 TU; Table 2, Fig. 1) suggest that these waters have long residence time and recharge of such water is likely to take place from the recharge area located in North 24-Parganas and Nadia districts (Fig. 1 inset) in the north of the wetlands. The shallow groundwater in the central and southern parts of the wetland has higher tritium content than the western part. This indicates local recharge from surface water bodies in the central and southern parts of ECW. At Bamanghata (IMS no. 6) the tritium value of deep groundwater is similar to that of the shallow groundwater indicating the mixing of groundwater of shallow and deep aquifers. This is corroborated by the sub-surface lithological set up where sand occurs continuously from the top of the geological sequence. Therefore, it can be inferred that pumping for domestic and irrigation purposes from various depth levels has resulted in vertical mixing of groundwater in some places.

The plots of $\delta \mathrm{D}$ versus $\delta^{18} \mathrm{O}$ (Fig. 6a) for both shallow and deep groundwater of the area, fall slightly below the GMWL and LMWL of Mukherjee (2006). This indicates an origin from rain with some evaporation prior to or during infiltration. The slight deviation of the samples from the LMWL 
Table 2. Result of isotope analysis of groundwater and surface water of ECW.

\begin{tabular}{|c|c|c|c|c|c|c|c|}
\hline Sl. No. & $\begin{array}{l}\text { IMS } \\
\text { number }\end{array}$ & Location & $\begin{array}{l}\text { Screen } \\
\text { depth } \\
(m)\end{array}$ & Water type & $\begin{array}{l}\delta D \\
\text { VSMOW } \\
\% o\end{array}$ & $\begin{array}{l}\delta^{18} O \\
\text { VSMOW } \% o\end{array}$ & $\begin{array}{l}\text { Tritium } \\
(T U)\end{array}$ \\
\hline 1 & 1 & Chaynabi & 76 & $\begin{array}{l}\text { Groundwater } \\
\text { (Deep) }\end{array}$ & -29 & -4.0 & $<0.53$ (Apparent 0.2) \\
\hline 2 & 3 & $\begin{array}{l}\text { Trinath } \\
\text { palli }\end{array}$ & 12 & $\begin{array}{l}\text { Groundwater } \\
\text { (Shallow) }\end{array}$ & -28 & -3.6 & $<0.76$ (Apparent 0.4) \\
\hline 3 & 6 & $\begin{array}{l}\text { Baman } \\
\text { ghata }\end{array}$ & 92 & $\begin{array}{l}\text { Groundwater } \\
\text { (Deep) }\end{array}$ & -27 & -3.3 & $4.5 \pm 0.3$ \\
\hline 4 & 4 & $\begin{array}{l}\text { Bamanghata } \\
\text { bazaar }\end{array}$ & 22 & $\begin{array}{l}\text { Groundwater } \\
\text { (Shallow) }\end{array}$ & -32 & -4.5 & $5.5 \pm 0.4$ \\
\hline 5 & 7 & $\begin{array}{l}\text { Pratap } \\
\text { nagar }\end{array}$ & 76 & $\begin{array}{l}\text { Groundwater } \\
\text { (Deep) }\end{array}$ & -32 & -4.9 & $<1.1$ (Apparent 0.5) \\
\hline 6 & 8 & $\begin{array}{l}\text { Pratap } \\
\text { nagar Bazar }\end{array}$ & 30 & $\begin{array}{l}\text { Groundwater } \\
\text { (Shallow) }\end{array}$ & -29 & -4.3 & <1.1(Apparent 0.5) \\
\hline 7 & 12 & Dihi Uttar para & 305 & $\begin{array}{l}\text { Groundwater } \\
\text { (Deep) }\end{array}$ & -28 & -4.0 & $<0.6$ (Apparent 0) \\
\hline 8 & 10 & Dihi & 28 & $\begin{array}{l}\text { Groundwater } \\
\text { (Shallow) }\end{array}$ & -25 & -3.0 & $3.9 \pm 0.3$ \\
\hline 9 & 2 & Goaltala Bheri & - & $\begin{array}{l}\text { Surface water } \\
\text { (Fishery) }\end{array}$ & -4 & 0.8 & - \\
\hline 10 & 5 & Bhangar Canal & - & $\begin{array}{l}\text { Surface water } \\
\text { (Canal) }\end{array}$ & -27 & -3.9 & - \\
\hline 11 & 9 & $\begin{array}{l}\text { Kasia } \\
\text { danga }\end{array}$ & - & $\begin{array}{l}\text { Surface water } \\
\text { (River Bidyadhari) }\end{array}$ & -9 & -0.6 & - \\
\hline 12 & 11 & Dihi & - & $\begin{array}{l}\text { Surface water } \\
\text { (Fresh pond) }\end{array}$ & 13 & 4.7 & - \\
\hline 13 & 13 & Dhapa Durgapur & 90 & $\begin{array}{l}\text { Groundwater } \\
\text { (Deep) }\end{array}$ & - & - & $<0.6$ (Apparent 0) \\
\hline 14 & 14 & Saifarabad & 28 & $\begin{array}{l}\text { Groundwater } \\
\text { (Shallow) }\end{array}$ & - & - & <1.1 (Apparent 0.5) \\
\hline 15 & 15 & Kharamba & 90 & $\begin{array}{l}\text { Groundwater } \\
\text { (Deep) }\end{array}$ & - & - & $<0.7$ (Apparent 0.1) \\
\hline 16 & 16 & Kharamba & 15 & $\begin{array}{l}\text { Groundwater } \\
\text { (Shallow) }\end{array}$ & - & - & $6.6 \pm 0.4$ \\
\hline
\end{tabular}

Experimental precision for $\delta^{18} \mathrm{O} \sim \pm 0.1 \%$ and for $\delta \mathrm{D} \sim \pm 1 \%$; Tritium data are with one sigma uncertainties for some samples.

suggests that some evaporation of rainfall occurs prior to or during infiltration, or there might be some mixing of the infiltrating water with pre-existing soil moisture that has undergone several cycles of evaporation and wetting (Allison, 1982). $\delta \mathrm{D}$ and $\delta^{18} \mathrm{O}$ values of shallow and deep groundwater (Table 2) are similar as the recharge area for both are quite close and the local climatic condition is quite similar so as not to cause significant isotopic variation.

Shivanna et al. (1999) reported stable isotopic results for groundwater samples collected from various depths in selected areas of South 24-Parganas district of West Bengal. They inferred that there is limited connectivity between deep and shallow groundwater in South 24-Parganas. According to Misra (2001) stable isotope study of South 24-Parganas reveals that shallow groundwater (depth $<70 \mathrm{~m}$ ) is slightly depleted in $\delta \mathrm{D}$ and $\delta^{18} \mathrm{O}$ content compared to that of deep groundwater (depth $>70 \mathrm{~m}$ ). In this region, $\delta \mathrm{D}$ and $\delta^{18} \mathrm{O}$ values ranges from $-37 \%$ oto $-22 \%$ and from $-6 \%$ o to $-3.5 \%$, respectively and in deep groundwater they range from $-16 \%$ to $-9 \%$ and from $-6 \%$ to $-3 \%$, respectively. The $\delta \mathrm{D}$ versus $\delta^{18} \mathrm{O}$ plots (Shivanna et al., 1999; Misra, 2001) indicate that most of the samples fall on or above the LMWL revealing that these waters are not affected by evaporation. The plots also fall in two different groups indicating that there is no interaction between the two groups of groundwater (Fig. 6a). But moving further north, towards the present area, plots of stable isotope data indicates a different hydrogeological environment. In and around ECW, the plots of $\delta \mathrm{D}$ versus $\delta^{18} \mathrm{O}$ for shallow and deep groundwater fall in a single cluster (Fig. 6a). It indicates that there is an interaction between the 


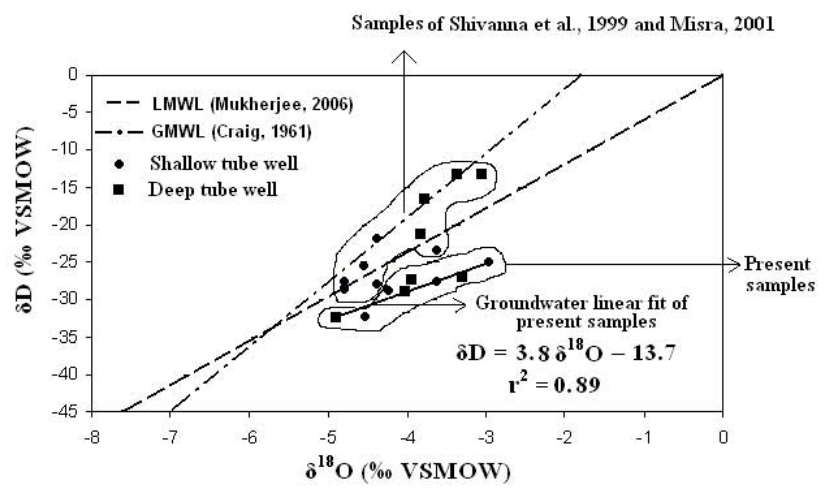

(a)

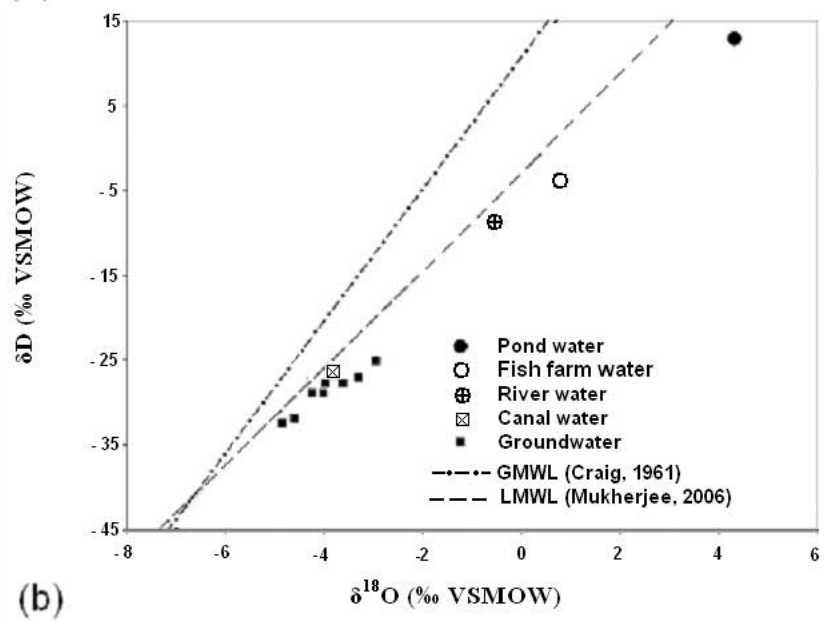

Fig. 6. Plots of $\delta \mathrm{D}$ versus $\delta^{18} \mathrm{O}$ along with GMWL and LMWL for (a) shallow and deep groundwater and (b) surface water and groundwater.

groundwater of two different depths in the area. This interaction is only possible when the top confining bed of the deep aquifer is discontinuous or permeable in nature. These conditions allow shallow groundwater to move downwards and mix with the groundwater of deep aquifer. The groundwater line $\left[\delta \mathrm{D}=3.8 \delta^{18} \mathrm{O}-13.7\left(r^{2}=0.89\right)\right]$, obtained by least square fit method using the groundwater of present area, has a lower slope than both LMWL and GMWL (Fig. 6a). This indicates that the isotopic composition of the groundwater of the area is also influenced by evaporation as well as precipitation. Therefore, the area south of Sonarpur (Fig. 1) may be a better location to treat the sewage water than within ECW.

\subsubsection{Surface water}

All surface water samples (fish farm water, canal water, river water and pond water) plot below the GMWL and LMWL (Fig. 6b) suggesting evaporation. The water sample of Bhangar Canal (IMS no. 5; Fig. 1), with $\delta^{18} \mathrm{O}$ values of $-3.9 \%$ o shows maximum depletion because of short residence time of the water in the canal inhibiting evaporation.
The isotopic composition of this canal water is similar to that of the groundwater because this water is the wastewater of the city of Kolkata, which is a mixture of groundwater and surface water. The maximum enrichment of $\delta^{18} \mathrm{O}$ is in pond water (IMS no. 11 having $\delta^{18} \mathrm{O}$ value $4.7 \%$ ) which indicates prolong evaporation from a small area.

The "deuterium excess" values $d\left(d=\delta \mathrm{D}-8 \delta^{18} \mathrm{O}\right.$, Dansgaard, 1964) for surface water ranges from $-50.5 \%$ o to $4.5 \%$ o with a mean value of $-15.1 \%$. This indicates that evaporation is probably occurring from the surface water bodies and results in the stable isotope compositions lying below GMWL and LMWL (Fig. 6b).

\section{Discussion}

The results described here demonstrates the degree to which the wetland geology and wetland groundwater sources may vary over comparatively short distances and time scale in an apparently small homogeneous wetland illustrating the importance of determining the hydrostratigraphy of inland freshwater wetlands. The variation in the isotope data also demonstrates the potential of isotopes to understand wetland hydrological dynamics, including differences in the recharge area and aquifer vulnerability to groundwater pollution.

This study indicates that absence of the top aquitard at places within the wetland may act as "stratigraphic shortcuts". These "shortcuts" are recharge areas and make easy passage for pollutants to flow from the wetlands and agricultural land into the underlying aquifer and deteriorate the quality of groundwater. The isotope data confirms that in general, the isotope composition of groundwater of the wetland is similar to the mean weighted annual precipitation composition. Variations may result depending on types of soil and vegetation, unsaturated flow through heterogeneous porous media, evapotranspiration, seasonal variations, longterm climatic variations and residence time in the recharge zone (Clark and Fritz, 1997). For the present area, the effect of evaporation before or during infiltration and seasonal variability may be important. In general the ECW recharge is dominated by monsoonal precipitation, although there might be some contribution from the pre-monsoonal rainfall and also from the wetland itself. The effect of these recharges would be most dominant in the shallow groundwater. However, it should be noted that as all groundwater and surface water samples were collected at the same time of the year, no study of seasonal trends was undertaken. The groundwater $\delta^{18} \mathrm{O}$ range of the ECW is within the range of monsoon precipitation composition range of Mukherjee (2006) and Sengupta and Sarkar (2006) during 2004-2005. This indicates that groundwater of the area is probably recharged primarily from precipitation with similar isotopic composition to the present. Similarity in $\delta \mathrm{D}$ and $\delta^{18} \mathrm{O}$ values of both shallow and deep groundwater indicates that the recharge areas for both are quite close and the local climatic condition 
of both the areas is quite similar. Present day precipitation in India is estimated to have a tritium content of around 1.33 TU-6.32 TU (estimated at Kozhikode, Kerala; Source: www.isohis.iaea.org). In Tuscon basin of southwest USA bomb tritium in precipitation was augmented by industrial tritium releases in 1970s. It was "rained out" of Tucson precipitation by 1991 and since then rain contains $4.6 \mathrm{TU}-$ 6.7 TU of tritium representing natural cosmogenic production (Eastoe et al., 2004). Similarity of tritium value range in rainwater of India and USA with that of the shallow groundwater of the area also indicates that the aquifer is directly recharged from monsoonal precipitation.

Generally, the depth-wise variation of tritium data described here illustrates the potential of radioactive isotopes to differentiate recharge areas of groundwater of different depths. Though, depletion or enrichment of $\delta^{18} \mathrm{O}$ and $\delta \mathrm{D}$ with depth was not observed, tritium content of groundwater from shallow aquifer is in general more than that of deep aquifer. Exception to this has been observed at one location within the ECW where the tritium content is $4.5 \mathrm{TU}$. Therefore, shallow groundwater has been recharged from local surface water bodies whereas the deep groundwater has been recharged from sources located far away from the wetland. Deep groundwater where tritium content is similar to that of the shallow groundwater indicates absence of any lithological barrier and mixing of groundwater of shallow and deep aquifers due to heavy pumping for domestic and irrigation purposes from various depth levels. The slight deviation of the samples from the LMWL suggest that some evaporation of rainfall occurs prior to or during infiltration, or there might be some mixing of the infiltrating water with preexisting soil moisture that has undergone several cycles of evaporation and wetting. Harvey et al. (2005) concluded that the recharge in their study area in Bangladesh is very complex: in addition to direct infiltration from precipitation, recharge may also take place from the bottom of ponds, ox-bow lakes, rivers, and re-infiltration of groundwater withdrawn for irrigation. Such a scenario is probably also true for the present wetland especially in areas where the top aquitard is absent and the piezometric surface is below the water table of the aquitard. The implication of this in the context of the present study is that if the wastewater contains heavy metals, a part of those metals may travel towards Kolkata's well intakes. This is in agreement with the works of Ghosh et al. (2001), Sikdar et al. (2002), Sikdar and Bhattacharya (2003) and Sahu and Sikdar (2007) who reported the presence of heavy metals such as cadmium, chromium, nickel, lead and copper in groundwater of both shallow and deep aquifers of the wetland area and Kolkata city. Therefore, surface water and groundwater interaction should be minimized in and around wetland areas by regulating tubewell operation time, introducing treated surface water supply system and artificially recharging the wetland aquifer by roof top rainwater harvesting in high-rise building and in nearby heavy water consuming industries.
In general the results described in this paper have several implications for the study of wetland hydrology. This illustrates the importance of determining the hydrostratigraphy of inland freshwater wetlands and also indicates that the recharge area of wetland may vary over short distances. The variation in the isotope data also demonstrates the potential of isotopes to understand wetland hydrological dynamics especially groundwater mixing and contamination.

\section{Conclusions}

Subsurface geological study reveals that the Quaternary aquifer of the ECW is sandwiched between two aquitards made of silty clay/clay. At places the top aquitard is absent and sands of various grades are observed throughout the geological column. These areas are recharge zones and make easy passage for pollutants to flow from the wetlands and agricultural land into the underlying aquifer. These pollutants deteriorate the quality of groundwater. The abstraction of the groundwater in the ECW has increased over the years and at present is over-extracted to the tune of $65 \times 10^{3} \mathrm{~m}^{3} /$ day. The effect of over-extraction is manifested dominantly in the shallow groundwater which is polluted by heavy metals such as cadmium, chromium, nickel, lead and copper. The stable isotopic composition of shallow and deep groundwater, point towards their origin from rain with some evaporation prior to or during infiltration. The recharge area for both is quite close and the local climatic condition is quite similar. Stable isotope content also indicates that there is no connectivity between deep and shallow groundwater in areas south of the ECW. But in the ECW, there is an interaction between the groundwater of two different depths as revealed by the isotope composition and presence of heavy metals in deep aquifer. Therefore, the area south of the ECW may be a better location to treat the sewage water than within the ECW. Similarity of tritium value range in rainwater with that of the shallow groundwater of the area indicates that the aquifer is directly recharged from monsoonal precipitation. The tritium content of groundwater from shallow aquifer is in general more than that of deep aquifer. Therefore, shallow groundwater has been recharged from local surface water bodies whereas deep groundwater has been recharged from sources located far away from the wetland. At places where deep groundwater has tritium content similar to that of shallow groundwater indicates absence of any lithological barrier and mixing of groundwater of shallow and deep aquifers due to heavy pumping for domestic and irrigation purposes from various depth levels. Any additional abstraction of groundwater will increase the stress on the aquifer which may lead to further contamination of groundwater due to leakage of water from the overlying aquitard. Therefore, it is imperative to reduce the surface water-groundwater interaction in ECW. 
Acknowledgements. The authors are thankful to C. I. Voss, Research Hydrologists, United States Geological Survey (USGS), H. A. Michael, Assistant Professor, Department of Geological Sciences, College of Marine and Earth Studies University of Delaware, R. L. Michel of the USGS, and A. Sarakar, Department of Geology and Geophysics, and Co-ordinator, NAFSIG, Indian Institute of Technology (IIT), Kaharagpur for their help in isotope analysis. The authors also convey thanks to the Director, IISWBM for providing necessary infrastructure and encouragement for the research work. The second author is thankful to Council of Scientific and Industrial Research (CSIR), India for their financial assistance in carrying out the research work.

Edited by: N. Romano

\section{References}

Aggarwal, P. K., Basu, A. R., Kulkarni, K. M., Froehlich, K., Tarafdar, S. A., Ali, M., and Hussain, A.: A report on isotope hydrology of groundwater in Bangladesh: Implications for characterization and mitigation of arsenic in groundwater, International Atomic Energy Agency-TC Project BGD/8/016, 64 pp., 2000.

Allen, J. R. L.: A review of origin and characteristics of recent alluvium sediments, Sedimentology, 5, 89-191, 1965.

Allison, G. B.: The relationship between 180 and deuterium in water and sand columns undergoing evaporation, J. Hydrol., 55, 163-176, 1982.

Banerjee, I. and Khan, D. K.: Hydregeology and groundwater development potential of 24- Parganas district, West Bengal, Central Ground Water Board Technical Report D, 24, 1-31, 1982.

Barui, N. C. and Chanda, S.: Late Quaternary pollen analysis in relaton to palaeoecology, biostratigraphy and dating of Calcutta peat, Indian National Science Academy, 58B(4), 191-200, 1992.

Biswas, A. B. and Saha, A. K.: Groundwater condition of Calcutta Metropolitan Area, Unpublished Project Report, Centre for Study of Man and Environment, Kolkata, 1986.

Basu, A. R., Jacobsen, S. B., Poreda, R. J., Dowling, C. B., and Aggarwal, P. K.: Response to Harvey, 2002: Groundwater flow in the Ganges delta, Science, 296, 15-63, 2002.

Chaterji, G. C., Biswas, A. B., Basu, S., and Niyogi, B. N.: Geology and groundwater resources of the Greater Calcutta Metropolitan Area, West Bengal, Bulletin Geological Survey of India Series, B(21), 1-150, 1964.

Clark, I. D. and Fritz, P.: Environmental Isotopes in Hydrogeology, Lewis Publishers, Boca Raton, Florida, 328 pp., 1997.

Clay, A., Bradley, C., Gerrard, A. J., and Leng, M. J.: Using stable isotopes of water to infer wetland hydrological dynamics, Hydrol. Earth Syst. Sci., 8, 1164-1173, 2004, http://www.hydrol-earth-syst-sci.net/8/1164/2004/.

Cooper, D. J., MacDonald, L. H., Wenger, S. K., and Woods, S. W.: Hydrologic restoration of a fen in Rocky Mountain National Park, Colorado, USA, Wetlands, 18, 335-345, 1998.

Craig, H.: Isotopic variations in meteoric water, Science, 133, 1702-1703, 1961.

Dansgaard, W.: Stable isotopes in precipitation, Tellus, 16, 436467, 1964

Dray, M.: Contribution of isotopic techniques in the determination of the relationship of surface water/groundwater in Bangladesh (Ganges and Brahmaputra area), Proceedings of the National
Symposium on River Basin Development, Dacca, Bangladesh, 158-170, 1983.

Drexler, J. Z., Bedford, B. L., DeGaetano, A. T., and Seigal, D. I.: Quantification of water budget and nutrient loading in a small peatland, Journal of American Water Resource Association, 35, 753-769, 1999.

Eastoe, C. J., Gu, A. and Long, A.: The Origins, Ages and Flow Paths of Groundwater in Tuscon Basin: Results of a study of Multiple Isotope Systems, Groundwater Recharge in a Desert Environment: The Southwestern United States, Water Science and Application 9, American Geophysical Union, 217-234, 2004.

Folk, R. L.: Petrology of sedimentary rocks, Hemphill's, 170 pp., 1968.

Ghosh, A. and Roy, A.: Aquifer characteristics and development of groundwater at Sonarpur Dist. 24-Parganas (South), Proceedings of the Seminar on Aquifer characteristics and groundwater management in Eastern India, Department of Geological Sciences, Jadavpur University, Calcutta, 27-39, 1996.

Ghosh, N. C., Chatterjee, T. K., Gupta, A., and Saha, D.: Heavy metal concentration in groundwater of Greater Calcutta (Kolkata), West Bengal, India, Indian J. Geol., 73(1), 55-66, 2001.

Hait, A. K., Das, J. K., Ghosh, S., Ray, A. K., Saha, A. K., and Chanda, S.: New dates of Pleisto-Holocene subcrop samples from South Bengal, India, Indian J. Earth Sci., 23(2), 79-82, 1996.

Harvey, C. F., Swartz, C. H., Badruzzaman, A. B. M., Keon-Blute, N., Yu, W., Ali, M. A., Jay, J., Beckie, R., Niedan, V., Brabander, D., Oates, P. M., Ashfaque, K. N., Islam, S., Hemond, H. F., and Ahmed, M. F.: Groundwater arsenic contamination on the Ganges Delta: biogeochemistry, hydrology, human perturbations, and human suffering on a large scale, C. R. Geosci., 337, 285-296, 2005.

Klump, S., Kipfer, R., Olaf, A. C., Harvey, C. F., Brennwald, M. S., Khandkar, N. A., Badruzzaman, A. B. M., Hug, S., and Imboden, D. M.: Groundwater dynamics and arsenic mobilization in Bangladesh assessed using noble gases and tritium, Environ. Sci. Technol., 40, 243-250, 2006.

Masch, F. D. and Denny, K. J.: Grain size distribution and its effect on permeability of unconsolidated sand, Water Resour. Res. 2, 665-672, 1966.

Misra, A. K.: Hydrogeology and groundwater resource management in South 24 Parganas District and Calcutta Municipal Corporation area, West Bengal, Unpublished Ph.D. thesis, Jadavpur University, India, 242 pp. 2001.

Mitra, A. and Gupta, S. K.: Evaluation of groundwater pollution potential of sewage irrigated vegetable farming area of the eastern fringe of Calcutta City, in: Water, Sanitation and Health, edited by: Chorus, I., Ringelband, U., Schlog, G., and Schmoll, O.: Proceedings of the International Conference of Germany, WHO, Water Series, IWA Publishing, London, 261-267, 2000.

Mukherjee, A.: Deep Groundwater flow and chemistry in the Arsenic affected Western Bengal Basin, West Bengal, India, Unpublished Ph.D. thesis, University of Kentucky, USA, 248 pp. 2006.

Mukherjee, A., Fryar, A. E., and 5 Howell, P. D.: Regional hydrostratigraphy and groundwater flow modeling in the arsenicaffected areas of the western Bengal basin, West Bengal, India, 
Hydrogeol. J., 15, 1397-1418, 2007.

Niyogi, B. N., Das Gupta, A. V., and Gangopadhyay, M. K.: A Preliminary Report of the exploration of groundwater resources of the Calcutta Metropolitan District, unpublished report, Geological Survey of India, 10 pp., 1966.

Owen, C. R.: Water budget and flow pattern in an urban wetland, J. Hydrol., 169, 171-187, 1995.

Sahu, P. and Sikdar, P. K.: Hydrochemical framework of the aquifer in and around East Kolkata Wetlands, West Bengal, India, Environ. Geol., 55(4), 823-835, 2007.

Sengupta, S. and Sarkar, A.: Stable isotope evidence of dual (Arabian and Bay of Bengal) vapour sources in monsoonal precipitation over north India, Earth Planet. Sci. Lett., 250, 511-521, 2006.

Sen, P. K. and Banerjee, M.: Palyno-plankton stratigraphy and environmental changes during the Holocene in the Bengal Basin, India, Rev. Palaeobot. Palynolo., 65, 25-35, 1990.

Shivanna, K., Sharma, S., Sinha, U. K., Nair, A. R., Navada, S. V., Ray, A., Talukdar, T., Mehta, B. C., and Ghosh, A. K.: Arsenic pollution in ground water of West Bengal, Proceedings of the workshop on Groundwater Pollution and Its Protection with Special Reference to Arsenic Contamination, Central Ground Water Board, Calcutta, 1-16, 1999.

Sikdar, P. K.: Geology of the Quaternary aquifers of the twin city of Calcutta-Howrah, J. Geol. Soc. India, 56(8), 169-186, 2000.
Sikdar, P. K.: Hydrogeology of the area in an around Calcutta and Howrah municipal corporation with special emphasis on the management of groundwater resources, $\mathrm{Ph} . \mathrm{D}$. thesis, University of Kolkata, West Bengal, India, 163 pp., 1996.

Sikdar, P. K. and Bhattacharya, P.: Groundwater risk analysis and development plan of Calcutta, in: Environmental issues for the 21st Century, edited by: Das Gupta, S. P., Mittal Publishers, New Delhi, 83-119, 2003.

Sikdar, P. K. and Dasgupta, S. P.: Pollution risk analysis of groundwater of Calcutta and Howrah cities, Indian Minerals, 50(4), 397-402, 1997.

Sikdar, P. K., Mondal, S., Saha, L., Sarkar, S. S., and Banerjee, S.: Environmental impact assessment of a proposed info-tech complex in East Calcutta wetlands, The Environmentalist, 22(4), 241-260, 2002.

Soulsby, C., Malcolm, R., Helliwell, R., Ferrier, R. C., and Jenkins, A.: Isotope hydrology of the Allta' Mharcaidh catchment, Cairngorms, Scotland: implications for hydrological pathways and residence times, Hydrol. Process., 14, 747-762, 2000.

Stüben, D., Berner, Z., Chandrashekharam, D., and Karmakar, J.: Arsenic enrichment in groundwater of West Bengal, India: geochemical evidence for mobilization of As under reducing conditions, Appl. Geochem., 18(9), 1417-1434, 2003. 